\title{
Performance of Murrah Buffalo and their Calves under Weaning and Suckling System
}

\author{
Ajesh Kumar, M.L. Kamboj, Santosh Kumar, Suresh Chandra Jingar*, \\ Pankaj Lawania and H.L. Bugaliya
}

\author{
National Dairy Research Institute, Karnal-132 001, Haryana, India \\ *Corresponding author
}

\section{A B S T R A C T}

In the present study performance of Murrah buffalos calves $(n=16)$ were evaluated to test the hypothesis of nursing of calves by their own mothers increases the body weight of calves and decreases the milk production. 16 pregnant Murrah buffaloes

\section{Keywords}

Milk yield, Calves, Suckling,

Weaning, Body weight

Article Info

Accepted:

26 June 2017

Available Online:

10 July 2017 milked under restricted suckling system during previous lactation and with equal parities and expected milk production ability were randomly divided into two groups comprises 8 in each as G1 (Suckled) and G2 (W e a ned). The calves from group of G1 buffalo were allowed to suckle their respective dam's milk however, calves from group G2 were weaned immediately after birth and fed colostrum and milk artificially. Average daily milk yield of weaned group G2 buffalo was significantly $(\mathrm{P}<0.01)$ lower in comparison to suckled group buffalo G1 (6.31 vs. $8.99 \mathrm{~kg} /$ day). Although calves of both the groups were born with similar body weight at birth $(\mathrm{P}>0.05)$ but body weight at 180 days of age were $113.12 \pm 2.81$ vs. $122.77 \pm 2.63 \mathrm{~kg}$ in group G2 \& G1 respectively, which was significantly $(\mathrm{P}<0.05)$ higher in suckled group buffalo calf resulted significantly $(\mathrm{P}<0.05)$ average daily gain $(A D G)$ was higher in case of suckled calves $(0.512 \pm 0.03 \mathrm{~kg} / \mathrm{day})$ than weaned calves $(0.451 \pm 0.02 \mathrm{~kg})$. The present study doesn't support the above hypothesis therefore, it is concluded that suckling have positive effect on milk production and calve body weight gain in Murrah buffalo.

\section{Introduction}

Buffalo milk production has a major share $(56 \%)$ in India's total milk production which is mainly contributed by small and marginal farmers of rural farmers. Rural buffalo rearing is still under traditional management system and calves are allowed to suckle their dams for their milk feeding as well as letdown of milk (Kamboj and Tomer, 2002). Weaning system of calves rearing is recognized as scientific, hygienic and economic however, its results are not always satisfactory especially in case of buffalo (Kamboj et al., 2006, Smijisha and Kamboj 2012). Buffalo has strong maternal instinct consequently mother and young relationships are closely bonded. Buffalo calves are slow learners as compared to the crossbred cattle calves (Hagberg, 2003) and require more time to learn drinking of milk from the pail/bucket under artificial feeding (Smijisha, 2007) therefore, separation between buffalo dam and their calves becomes more stressful for both calve and dam in comparison to taurus cattle's calves (Foulkes, 2005). Benefits of suckling over weaning in buffalo calves have been recently reviewed by (Kamboj and Kumar, 2013) 
however, Bharti et al., (2015) concluded that weaning did not affect the health and immunity levels of buffalo calves as compared with natural suckling. In view of the aforesaid discussion, it is evident that there is little research work on the effect of weaning vis-à-vis suckling on milk production of buffalo dam and body weight gain of calves. Therefore, present study was designed to examine the effect of weaning on production performance of buffalo dam and growth performance of their calves.

\section{Materials and Methods}

The study was conducted on Murrah buffaloes maintained at Livestock research station of National Dairy Research Institute (NDRI), Karnal, Haryana, India situated at an altitude of 250 meters above mean sea level, latitude and longitude position being $29^{\circ} 42^{\prime \prime}$ $\mathrm{N}$ and $77^{\circ} 54$ " E respectively. The maximum ambient temperature in summer goes up to $45^{\circ} \mathrm{C}$ and absolute minimum temperature falls to around $4^{\circ} \mathrm{C}$ in winter. The average annual rainfall is about $700 \mathrm{~mm}$, most of which is received from early July to midSeptember with occasional winter showers in the months of December and January. For the present study 16 down calver buffaloes were selected from the Murrah buffalo herd maintained at the institute. To maintain the homogeneity in groups, selected buffaloes were divided into two group G1 (Suckling) and G2 (weaned) on the basis of their production ability, body weight and parity. Each group comprised 8 numbers of buffaloes. The buffalo were allotted on the basis of randomized block design method. The buffaloes from the group G1 (suckling) were allowed natural suckling of colostrum as well as milk and for let-down of milk and second group G2 (weaned) calves were weaned from their dams immediately after birth. The selected buffaloes were milked twice daily at 5.00 AM in the morning and 6:30 PM. in the evening. The total experimental period was 180 days. During the experimental period all buffaloes were kept under similar loose housing and fed same basal diet which includes green grasses, dry fodder and concentrate as per their requirement. Concentrates was given at the time of milking. All the experimental calves of both the groups were kept separately under loose housing pen fed as per NDRI feeding schedule (Table 1).

The calves from G1 group were allowed suckling for the let-down of milk at the start of milking. At the end of milking, the calves were again allowed to suckle the required amount of milk. The quantity of milk intake of the calves of G1 suckling group was recorded once in a week by complete milking of respective dam on the seventh day of every week using following formula-

Milk intake of suckling calf $=$ [Total milk yield of $7^{\text {th }}$ day-Average milk yield of 6 days]. To estimate the total Dry matter intake difference between offered dry matter and left over dry matter, if any, was measured next morning. The offered feed samples and milk were analyzed as per AOAC (1995).

\section{Statistical analysis}

The data obtained in the study were subjected to the statistical analysis as per procedure described by the Snedecor and Cochran (1994). The significance of the differences between the mean values of various parameters studies was tested by employing $\mathrm{Z}$ test using SYSTAT 12.0 (SPSS Inc. Chicago, IL, USA).

\section{Results and Discussion}

\section{Milk production}

Milk yield, which is one of the most important parameter of dairy farming, was assumed to reduce under present study. 
However, the result observed was in contrary to the hypothesis. Total milk yield during experiment were $1798.48 \pm 0.12$ and $1272.94 \pm 0.17 \mathrm{~kg}$ in group G1 (Suckled) and G2 (Weaned) respectively.

Differences between suckling and weaned buffalo cows total milk was highly significantly $(\mathrm{P}<0.01)$. The results were observed in the present study was in agreement with the previous report of Usmani and Inskeep (1989) who reported higher total milk yield in limited-suckled buffalo cow than non-suckled Nili-Ravi buffalo cows.

Milking buffalo with dummy calf were also enhance daily milk yield significantly in Murrah buffaloes to which calves were weaned at birth (Saini and Kamboj, 2012). Kaskous et al., (2006) reported that cow milked in the presence of their calves produced significantly higher milk than the cows milked without the presence of their calves during 91 days postpartum study.

The significant increases in milk yield in the suckled group of buffaloes may have been resulted either due to better let-down and efficient removal of milk from the udder and udder health (Saini and Kamboj, 2012) or due to higher secretion of oxytocin from posterior pituitary and lactogenic hormones, i.e. prolactin and growth hormone (Fulkerson et al., 1978, Lupoli et al., 2001). However, it needs to be established by extensive study in buffaloes.

\section{Calves performance}

Calves from Suckled (G1) and weaned (G2) group were consumed similar $(\mathrm{P}>0.05)$ amount of dry matter from fodder, feed \& concentrate and milk. Average milk intake was $2.72 \pm 0.06$ and $2.61 \pm 0.09 \mathrm{~kg} /$ day in weaned and suckled group of buffalo calves respectively. The trend of milk intake have been depicted in figure 1 which showed that milk intake up to first 3 weeks after birth was numerically higher in suckled group than the weaned group of calves, thereafter weaned calves recovered and maintain the normal intake and it was remained almost constant in both the groups.

Though the average milk intake was similar in both the groups but average dry matter intake from milk was significantly higher in suckled group (G1) as compared to the weaned group (G2) of buffalo calves $(\mathrm{P}<0.05)$.

Averages dry matter intake of calves from milk were $0.48 \pm 0.06$ and $0.58 \pm 0.02 \mathrm{~kg}$ in weaned and suckled group respectively. Higher dry matter intake through milk in suckled group of calves could be due to the better quality of residual milk as shown in table 2 .

Allowing suckling of residual milk to the calves did not affect the normal quality of buffalo (dam) milk and it was statistically similar $(\mathrm{P}>0.05)$ to weaned group of buffalo (G2).

Froberg et al., (2008) also observed that the milk suckled by restricted suckling calves had more fat than the parlour milk fed to artificially suckling calves (6.1 vs. 4.2\%). Sanh et al., (1997) and Mejia et al., (1998) showed that a high weight gain in suckled calves was due to higher fat content in the residual milk, but it could also be related to differences in milk intake.

Green fodder and concentrate intake and dry matter intake from green fodder and concentrate in both the group were similar $(\mathrm{P}>0.05)$. Calve from suckled (G1) and weaned (G2) group were consumed 42.68 \& $43.83 ; 6.91 \& 6.96 \mathrm{~kg}$ green fodder and concentrate respectively during whole period of experiment. 
Fig.1 Mean weekly milk intake (kg/day) in Murrah buffalo calves

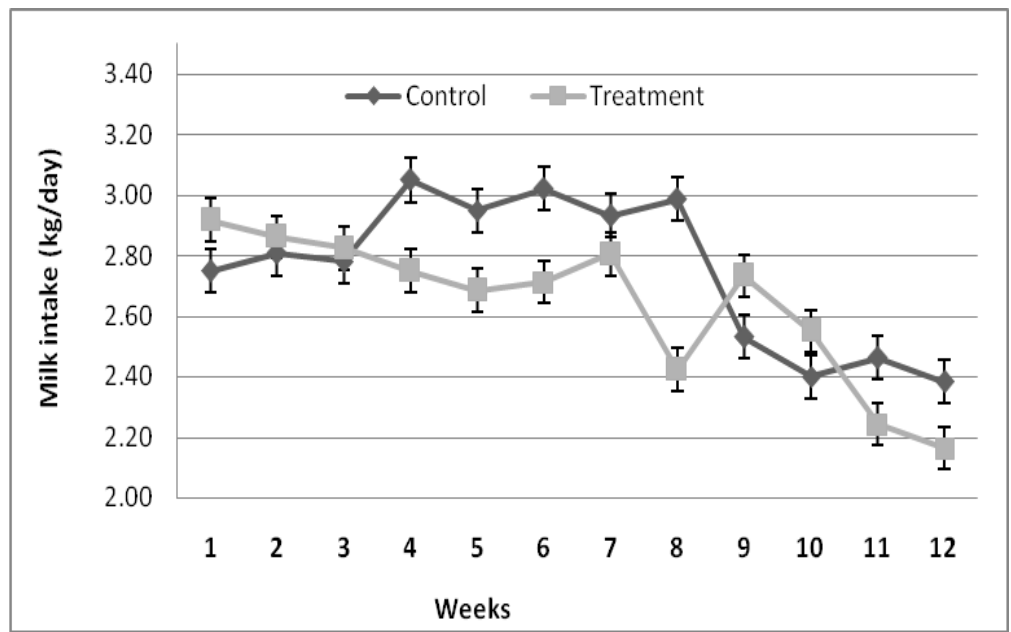

Fig.2 Mean weekly dry matter intake through milk (kg) in Murrah buffalo calves

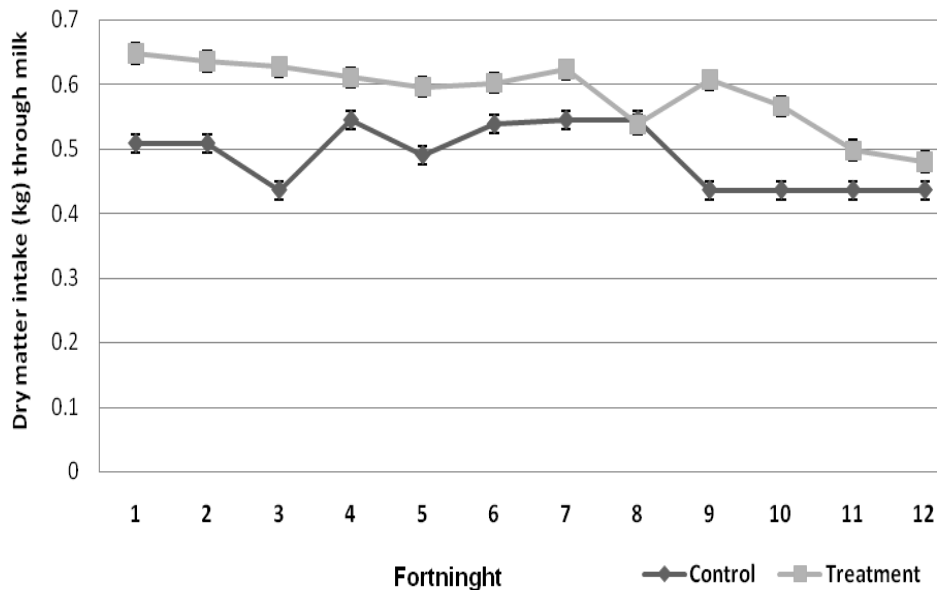

Fig.3 Dry matter intake (kg) through milk, green fodder and concentrate of Murrah buffaloes

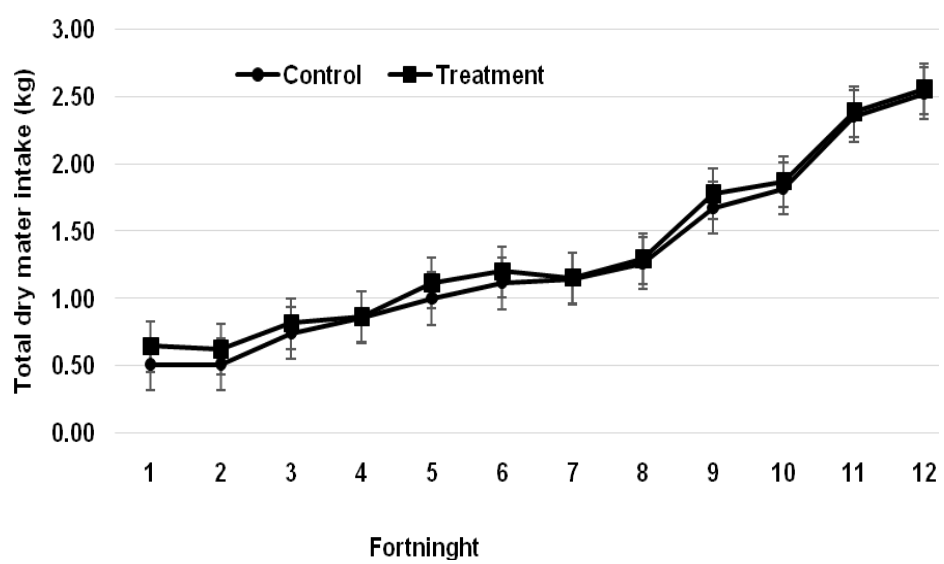


Fig.4 Mean body weight in Murrah buffalo calves

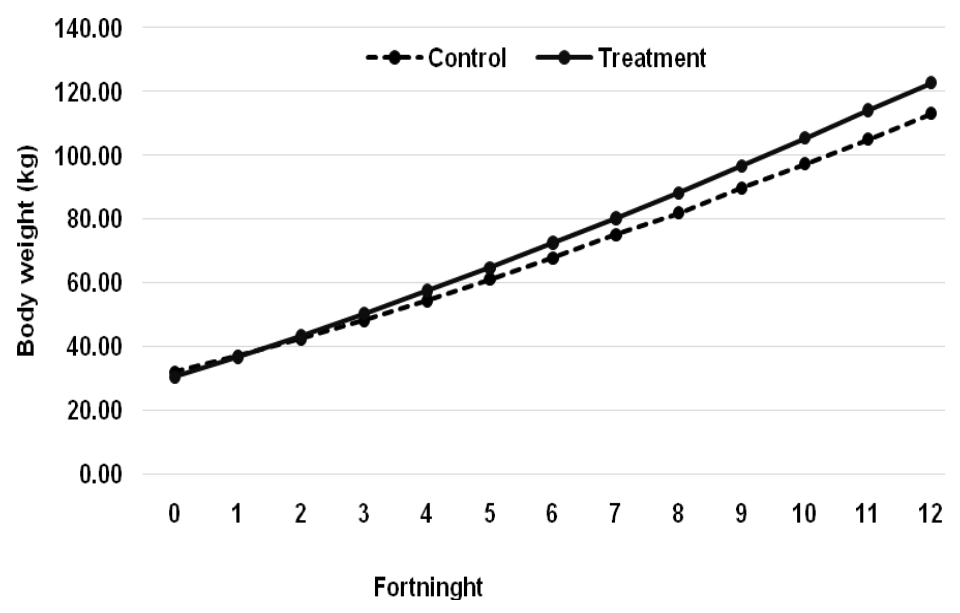

Fig.5 Mean body weight gain (kg/day) in Murrah buffalo calves

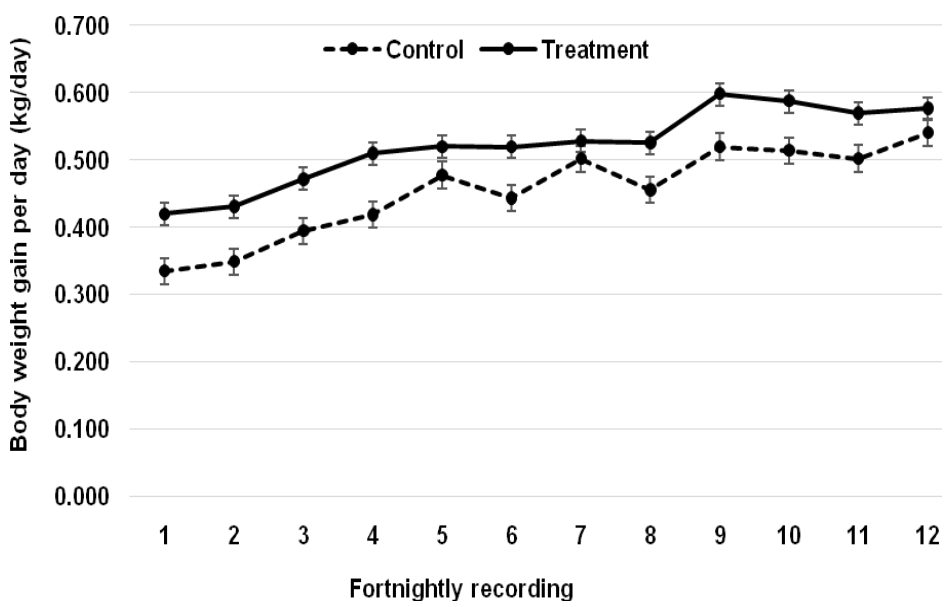

Table.1 Calve feeding schedule

\begin{tabular}{|c|c|c|c|c|}
\hline Age (months) & Colostrum & Whole milk & Concentrate mixture (kg) & Green fodder \\
\hline upto 5 days & $1 / 10^{\text {th }} \mathrm{Bwt}$ & - & -- & -- \\
\hline 5-30 days & & $1 / 10^{\text {th }}$ b.wt & -- & -- \\
\hline 1-2 months & & $1 / 15^{\text {th }}$ b.wt. & 0.120 & ad libitum \\
\hline 2-3 months & & $1 / 25^{\text {th }}$ b.wt. & 0.250 & ad libitum \\
\hline 3-4 months & -- & 0.650 & ad libitum \\
\hline 4-5 months & -- & 1.00 & ad libitum \\
\hline 5-6 months & -- & 1.500 & ad libitum \\
\hline
\end{tabular}

Table.2 Milk compositions (\%) of buffalo and offered to the calves

\begin{tabular}{|l|l|l|l|l|}
\hline Particulars & Weaned buffalo & Suckled buffalo & Weaned calves & Suckled calves \\
\hline Total solids & 18.16 & 17.97 & 18.16 & 22.19 \\
\hline SNF & 10.47 & 10.50 & 10.47 & 11.20 \\
\hline Fat & 7.69 & 7.48 & 7.69 & 10.99 \\
\hline
\end{tabular}


Table.3 Dry matter (\%) of feeds and fodder

\begin{tabular}{|l|l|}
\hline Feeds and fodder & DM \% \\
\hline Concentration & 89.78 \\
\hline Maize & 15.50 \\
\hline Oat & 14.35 \\
\hline Barseem & 14.84 \\
\hline
\end{tabular}

Dry matter intake from milk reported in the present study were in accordance to the previous studies (Babu and Pandey, 2000; Bharti PK, 2007) (Table 3).

\section{Gain in body weight}

The average birth weights of weaned and suckled groups were $(32.00 \pm 1.11$ and $30.62 \pm 0.41 \mathrm{~kg}$ ) not differ significantly $(\mathrm{P}>0.05)$ between the groups. However, average body weights at 90 days of age was reported $122.77 \pm 2.63$ in suckled G1 group in contrary to $113.12 \pm 2.81 \mathrm{~kg}$ in weaned G2 group calves, and were significantly $(\mathrm{P}<0.05)$ higher in suckled group of calves Similarly average daily weight gain over 180 day of age were also significantly $(\mathrm{P}<0.05)$ higher in suckled G1 group $(0.512 \pm 0.03 \mathrm{~kg} /$ day $)$ than weaned G2 group $(0.451 \pm 0.02 \mathrm{~kg})$ group of Murrah buffalo calves.

In the present study higher milk intake and better quality of residual milk could be contributed to attain higher body weight at 180 day of age in suckled group of calves. The present results were in accordance to the Sanh et al., 1997; Mejia et al., 1998; Roth et al., 2009.

Smijisha (2007) concluded that stimulated natural suckling may help to reach satiety and calves allowed to suckle had a higher level of oxytocin compared to bucket-fed calves (Lupoli et al., 2001) which may have also stimulated the higher weight gain in suckled group of calves. Total body weight gain is positively correlated to daily weight gain.
Smijisha (2007) reported that the average daily gain was significantly $(\mathrm{P}<0.05)$ higher in buffalo calves fed milk using a bottle with nipple than the bucket feeding calves. Khan and Preston (1992) also reported that the buffalo calves reared by restricted suckling of their dams showed better growth rate than reared on feeder or pail milk feeding. However, Bharti et al., (2015) observed no apparent $\quad(\mathrm{P}>0.05) \quad$ difference between restricted suckling and weaned calve group.

Based on the finding, the present study concluded that the allowing suckling to calve promote higher milk production and improve live weight gain of calve at weaning (90 days). Therefore, buffalo with higher maternal instinct may be allowed to suckling of calve for better milk production and higher growth rate of calve.

\section{Acknowledgement}

Authors are grateful to the Head of Division, LPM and Director, ICAR-NDRI, Karnal for providing fund, technical advices and facilities.

\section{References}

Babu, L. K. and H.N. Pandey. 2000. Behaviour and performance of individual versus group rearing crossbred calves fed on different levels of milk and skim milk. Ph.D.Thesis, Deemed University, IVRI, Izatnagar, Uttar Pradesh, India.

Bharti, P. K. and M. L. Kamboj. 2007. Effect 
of milk replacer feeding on growth rate, health and cost of feeding of crossbred calves. Ph.D. Thesis, Deemed University, N.D.R.I. Karnal, Haryana, India.

Bharti PK, Dutt T., Pandey H O, Patel B H M, Mahendran K, Kaswan S, BISWAS P and Upadhyay V K. 2015. Effect of weaning age on health of Murrah buffalo calves. Indian J. of Anim. Sci., 85 (12): 1370-1374.

Foulkes, D. 2005. Management of orphaned or weaned buffalo calves. www.nt.gov.au/dpifm

Froberg, S., E. Gratte, K.S. Sjaunja, I. Olsson, Berg, C., Orihuela, A., Galina, C.S., Garcia, L. and L. Lidfors. 2008. Effect of suckling (restricted suckling) on dairy cows' udder health and milk letdown and their calves' weight gain, feed intake and behaviour. Appl. Anim. Beh. Sci., 113: 1-14.

Fulkerson W J, Hooley R D and J K Findlay. 1978. Improvement in milk production of first calf heifers by multiple suckling. Aust. J. Agric. Res., 29:351-357

Hagberg, MS. 2003. Introduction to buffaloes. www.milkproduction.com pp. 1-6.

Kamboj M.L. and O.S. Tomer. 2002. Feeding management practices of calves of Nagori cattle under field conditions $10^{\text {th }}$ International Congress of AsianAustralian Association of Animal Production Societies (AAAP). Sept. 2327, 2002. New Delhi, India.

Kamboj M.L., B. Joshi, G. Singh and S. Prasad. 2006. A study on calf mortality in Nili-Ravi buffalo calves. Indian J. Dairy Sci., 59 (3): 181-84.

Khan, M.K. and T.R. Preston. 1992. Effect of restricted suckling on performance of Shorthorn and Sahiwal cows and calves in Pakistan. Livestock Res. Rural Dev., 4: 2.

Knowles, R. T. and M. D. Edwards. 1983. A comparison of the effects of restricted suckling and artificial calf rearing systems on dam and calf performance. Malay. Agric. J., 54:1-9.

Krishna Mohan, D. V. G., Das, D. R. and S. K. Ranjhan. 1987. Performance of young crossbred calves fed different levels of milk and different types of calf starters. 3. Growth, feed efficiency and cost of feeding calves from birth to three months of age. Indian J. Dairy Sci., 40: 18-22.

Kumar A and Komboj M L. 2013. Effect of weaning on performance and behaviour of calves and their dams in dairy cows A review. Indian J. Anim. Sci., 83 (10): 991-997.

Lupoli, B., Johansson, B., Uvnas-Moberg, K. and K. Svennersten- Sjaunja. 2001. Effect of suckling on the release of oxytocin, prolactin, cortisol, gastrin, cholecystokinin, somatostatin and insulin in dairy cows and their calves. $J$. Dairy Res., 68: 175-187.

Mejia, C. E. 1994. Effects of restricted suckling versus artificial rearing on milk production, calf performance and reproductive efficiency of dual purpose Mpwapwa cattle in a semiarid climate. MSc Thesis. Swedish University of Agricultural Sciences. Department of Animal Nutrition and Management. $64 p$.

Mejia, C. E., Preston, T. R. and P. Fajersson. 1998. Effects of restricted suckling versus artificial rearing on milk production, calf performance and reproductive efficiency of dual purpose Mpwapwa cattle in a semi-arid climate. Livestock Res. Rural Dev., 10: 1.

Metz J. 1987. Productivity aspects of keeping dairy cow and calf together in the postpartum period. Livest. Prod. Sci., 16: 385-394.

Roth, B. A., Barth, K., Gyagax, L. and E. Hillmann. 2009. Influence of artificial vs. mother- bonded rearing on sucking 
behaviour, health and weight gain in calves. Appl. Anim. Beh. Sci., 119: 143150.

Sanh, M.V., Preston, T.R. and P. Fajersson. 1995. Effects of restricted suckling versus artificial rearing on performance and fertility of Bostaurus and Bosindicus cows and calves in Tanzania. Livestock Res. Rural Dev., 6: 3.

Sanh, M.V., Preston, T.R. and L. Le Viet. 1997. Effects of restricted suckling versus artificial rearing on performance and fertility of crossbreed F1 (Holstein Friesian $\times$ Local) cows and calves in
Vietnam. Livestock Res. Rural Dev., 9: 4.

Smijisha, A.S. 2007. Effect of methods of feeding and individual housing on growth and health status of buffalo calves. M. V. Sc. Thesis, NDRI Deemed University, Karnal, India.

Smijisha A S and M.L. Kamboj. 2012. Colostrum intake of weaned buffalo calves reared under different management practices. Tamil Nadu J. Vet. Sci., 8 (1): 42-44.

Snedécor, G.W. and W.G. Cochran.1994. Statistical methods. $7^{\text {th }}$ Edn, Iowa State University Press. Iowa.

\section{How to cite this article:}

Ajesh Kumar, M.L. Kamboj, Santosh Kumar, Suresh Chandra Jingar, Pankaj Lawania and Bugaliya, H.L. 2017. Performance of Murrah Buffalo and their Calves under Weaning and Suckling System. Int.J.Curr.Microbiol.App.Sci. 6(7): 2452-2459.

doi: https://doi.org/10.20546/ijcmas.2017.607.348 